\title{
Molecular Detection of Diaporthe phaseolorum and Phomopsis longicolla from Soybean Seeds
}

\author{
A. W. Zhang, G. L. Hartman, B. Curio-Penny, W. L. Pedersen, and K. B. Becker
}

First, second, third, and fourth authors: Department of Crop Sciences, UIUC, Urbana, IL 61801-4723; fifth author: Perkin-Elmer Applied Biosystems, Foster City, CA 94404; and second author: 1101 W. Peabody Drive, USDA, ARS, Urbana, IL 61801-4723. Accepted for publication 9 June 1999.

\begin{abstract}
Zhang, A. W., Hartman, G. L., Curio-Penny, B., Pedersen, W. L., and Becker, K. B. 1999. Molecular detection of Diaporthe phaseolorum and Phomopsis longicolla from soybean seeds. Phytopathology 89:796-804.

Species-specific detection of Diaporthe phaseolorum and Phomopsis longicolla from soybean seeds was accomplished using polymerase chain reaction-restriction fragment length polymorphism (PCR-RFLP) and TaqMan chemistry. To use these detection systems, fungal DNA was released from soybean seed coats using an ultrasonic processor to break the cells. DNA fragment lengths ranged from 200 to 1,200 base pairs (bp), with the majority of fragments $<500 \mathrm{bp}$. Based on DNA sequences of the internal transcribed spacer (ITS) regions of ribosomal DNA, three TaqMan primer/probe sets were designed. Primer/probe set PL-5 amplified a 96-bp fragment within the ITS1 region of $P$. longicolla, D. phaseolorum var. caulivora, D. phaseolorum var. meridionalis, and D. phaseolorum var. sojae. Set PL-3 amplified a 86-bp DNA fragment within the ITS2 region of $P$. longicolla. Set DPC-3 amplified a 151-bp DNA fragment within the

ITS2 region of $D$. phaseolorum var. caulivora. TaqMan primer/probe sets were able to detect as little as $0.15 \mathrm{fg}$ (four copies) of plasmid DNA. When using PCR-RFLP for Diaporthe and Phomopsis detection, the sensitivity was as low as $100 \mathrm{pg}$ of pure DNA. Among 13 soybean seed lots from Italy and the United States, the total Diaporthe and Phomopsis detected using a traditional seed-plating technique ranged from 0 to $32 \%$. P. longicolla was most prevalent, followed by $D$. phaseolorum var. sojae. D. phaseolorum var. caulivora, which only occurred in $0.5 \%$ of the Italian seed lots, was not detected in the U.S. seed lots. D. phaseolorum var. meridionalis was not detected in either the U.S. or Italian seed lots. Using TaqMan primer/probe set PL-3, the frequency of $P$. longicolla was $18 \%$ in seed lot I3, similar to the frequency obtained from PCR-RFLP and potato dextrose agar plating detection. The frequencies of $D$. phaseolorum and $P$. longicolla in each seed lot obtained by the different detection methods were comparable with respect to total infection and individual species detection. However, TaqMan detection provided the fastest results of all the methods tested.
\end{abstract}

Phomopsis seed decay of soybean (Glycine $\max$ (L.) Merr.) is one of the major factors affecting seed quality (33). The fungi at first colonize seed coats and then cotyledons and plumules (34). Soybean seed mortality has been correlated with the incidence of fungi causing Phomopsis seed decay in seed lots (10), with a reduction in seed germination of up to $90 \%$ (16). Planting seed lots with infection levels greater than $40 \%$ has been reported to cause significant yield loss (37). Phomopsis seed decay not only reduces the quality of seeds used for planting by affecting germination potential but also can reduce the quality of seeds used for processing (32). The disease is caused primarily by Phomopsis longicolla T.W. Hobbs (teleomorph unknown) and also by Diaporthe phaseolorum (Cooke \& Ellis) Sacc. (anamorph P. phaseoli (Desmaz.) Sacc.) (13,31), which has three varieties, D. phaseolorum var. sojae (S.G. Lehman) Wehmeyer, D. phaseolorum var. caulivora K.L. Athow \& R.M. Caldwell, and D. phaseolorum var. meridionalis F.A. Fernández $(7,14,26)$. The epidemiological and pathogenic characteristics of these fungi vary, necessitating the identification of species and varieties in order to determine their importance and to design the best control strategies.

Corresponding author: G. L. Hartman; E-mail address: ghartman@uiuc.edu

Names are necessary to report factually on available data; however, the USDA neither guarantees nor warrants the standard of the product, and the use of the name by the USDA implies no approval of the product to the exclusion of others that may also be suitable.

Publication no. P-1999-0723-01R

This article is in the public domain and not copyrightable. It may be freely reprinted with customary crediting of the source. The American Phytopathological Society, 1999.
Among the diagnostic assays known to test for Phomopsis seed decay, one commonly used procedure is the potato dextrose agar (PDA) seed-plating bioassay (31). This assay uses morphological characteristics to identify the causal organisms. Both the assay and fungal identification may be rather labor intensive and timeconsuming. It is often difficult to determine if the isolated colonies are $P$. longicolla or one of the three varieties of $D$. phaseolorum.

Serological assays like enzyme-linked immunosorbent assays (ELISA) also have been used for detecting $D$. phaseolorum and $P$. longicolla in plants and seeds $(3,11,36)$ but are not used routinely in seed-testing laboratories because of insufficient specificity and sensitivity. Assay methods utilizing polymerase chain reaction (PCR) are being used more frequently for detecting fungal pathogens in plant tissues $(2,29,39)$, owing to their increased specificity and sensitivity compared with more traditional techniques.

PCR technology has the potential for widespread application in the field of plant pathogen detection and eventually could be used for pathogen-free seed certification and indexing programs. However, PCR-based approaches compared with ELISA-based methodology may be slower in achieving high-throughput sample analysis (8). For example, conventional PCR methods require the use of ethidium bromide-stained agarose gel electrophoresis often coupled with hybridization/blotting procedures or various types of capture techniques (35). Product detection in these instances is still labor intensive and time-consuming, making automation difficult and impractical.

Another PCR-based technique that has been used to successfully identify the species and varieties of Diaporthe and Phomopsis from soybean is PCR-restriction fragment length polymorphism (RFLP) (39). When using this method, accurate detection of these fungi in soybean seeds requires that the seeds are first incubated for a short period on PDA plates. DNA is extracted from mycelia 
growing on PDA plugs and subjected to PCR and enzyme digestion. The resultant fragments are then separated and detected by agarose gel electrophoresis and a blotting system. Thus, several steps are still necessary to obtain results.

In contrast, recent advances in PCR technology have obviated the need for post-PCR processing, increasing throughput via realtime detection and automated product analysis (22). A technique previously described in other systems utilizes TaqMan (PerkinElmer Applied Biosystems, Foster City, CA) chemistry $(9,12,21)$ and the 7700 Sequence Detection System (SDS) (Perkin-Elmer Applied Biosystems). TaqMan, originally termed the $5^{\prime}$ nuclease assay (15, 19,23), has been shown to be extremely sensitive, being able to detect as little as a single copy of DNA in certain systems $(9,12,21)$. During PCR, a fluorogenic probe, labeled on the $5^{\prime}$ end with a reporter dye and on the $3^{\prime}$ end with a quencher dye, anneals between the PCR primers. During the extension phase of PCR, Taq polymerase displaces a small portion at the $5^{\prime}$ end of the probe, creating a forklike structure. This, in turn, initiates the endogenous $5^{\prime}$ to 3 ' nucleolytic activity of Taq polymerase, cleaving the probe and freeing the reporter dye (19), which is capable of emitting an intense fluorescent signal (22). Repeated cycles of the PCR process result in exponential synthesis of the amplicon and a concomitant increase in reporter fluorescence automatically quantified by the SDS software (30).

Although advances such as these have significantly increased speed as well as ease of PCR detection and analysis, DNA sample preparation, a challenging and sometimes rate-limiting step, remains to be addressed. Several protocols are currently available for this purpose $(4,6,17,18,25)$, but they involve multiple steps. Further, some methods include preculture and immunocapture steps prior to amplification in order to increase the specificity of PCR detection $(1,28,30)$. These purification steps are often necessary when isolating nucleic acids from plants, as plant tissues harbor inhibitors that often interfere with or completely inhibit the basic PCR process. However, commercial kits such as GeneReleaser (BioVentures, Inc., Murfreesboro, TN) and FastDNA (Bio 101, Inc., Vista, CA) $(5,20)$ facilitate DNA preparation from plants, avoiding retention of inhibitors.

With regard to soybean seeds specifically, it is critical to break the hard, oily seed cells in order to release fungal DNA. Since PCR requires only a minute quantity of template DNA for successful amplification, it may be possible to utilize a simple extraction procedure that yields less DNA than some of the commercial kits yet requires a significantly smaller amount of time.

Keeping in mind the worldwide importance and implications of successful soybean pathogen diagnosis, this study was aimed at improving soybean DNA preparatory and detection methodologies. The objectives were to (i) develop a fast and economical DNA extraction method that can be utilized on a single soybean seed or PDA plug with mycelia growing from infected seeds, (ii) evaluate the utility of the TaqMan/SDS homogeneous assay as a quick method to identify and detect $D$. phaseolorum and $P$. longicolla from soybean seeds, and (iii) evaluate the efficiency of PCR-RFLP from PDA plugs with mycelia growing from infected seeds for identification of $D$. phaseolorum and P. longicolla present in soybean seed lots compared with the conventional PDA plating method.

\section{MATERIALS AND METHODS}

DNA extraction. All soybean seeds were treated with $95 \%$ ethanol for $30 \mathrm{~s}, 0.5 \% \mathrm{NaOCl}$ for $1 \mathrm{~min}, 2.5 \%$ paraquat (Gramoxone; Zeneca Corp., Wilmington, DE) for $2 \mathrm{~min}$, and rinsed three times with double-distilled (dd) $\mathrm{H}_{2} \mathrm{O}$ prior to all extraction methods.

Surface-disinfected soybean seeds were squeezed to release seed coats that were individually placed into a $1.5-\mathrm{ml}$ microfuge tube with $250 \mu \mathrm{l}$ of extraction buffer $(50 \mathrm{mM}$ Tris, $\mathrm{pH} 8.0 ; 10 \mathrm{mM}$ EDTA, pH 8.0; $100 \mathrm{mM} \mathrm{NaCl} ; 1.0 \%$ [wt/vol] sodium dodecyl sul- fate; and $10 \mathrm{mM} \beta$-mercaptoethanol). Three methods were tested to break the seed coat cells. (i) Seed coats were ground in liquid nitrogen. (ii) Seed coats were added to zirconium beads $(0.5 \mathrm{~mm}$ in diameter; one-fifth of the total volume), and the mixture was treated with a Mini-Beadbeater 3110 B $\times$ B (Biospec Products, Bartlesville, OK) for $10 \mathrm{~s}$. (iii) Seed coats were broken using an ultrasonic processor (Biospec Products) and a tapered microtip (5 mm in diameter) for $10 \mathrm{~s}$. After breaking the cells, regardless of the method, samples were mixed with $150 \mu$ of potassium acetate $(5 \mathrm{M}$, $\mathrm{pH}$ 5.2), incubated on ice for $20 \mathrm{~min}$, and then centrifuged at $12,000 \times g$ for $10 \mathrm{~min}$. Supernatants were saved. DNA concentrations extracted from the seed coats were determined by measuring the optical density at $260 \mathrm{~nm}\left(\mathrm{OD}_{260}\right)$ value using an UV spectrophotometer (Perkin-Elmer Applied Biosystems). DNA extraction from soybean leaf tissue was the same as the ultrasonic process treatment described for seed coats.

DNA extraction from mycelium growing out of seeds on PDA. Surface-disinfected soybean seeds (100 from each seed lot) were plated on PDA and incubated for 24 to $36 \mathrm{~h}$ at $27^{\circ} \mathrm{C}$. PDA plugs $(5 \times$ $10 \times 2 \mathrm{~mm}^{3}$, width $\times$ length $\times$ depth) with mycelial growth originating from single seeds were cut and placed into a $1.5-\mathrm{ml}$ microfuge tube with $250 \mu \mathrm{l}$ of extraction buffer. Cells were broken using the ultrasonic processor (described above). The mixtures were centrifuged, and the supernatants were saved as DNA extracts.

Qualification of DNA extracts from different treatments. Ten microliters of supernatant of DNA extract from each cell-breaking method was used in agarose gel electrophoresis. One microliter was used in PCR with primers ITS4 and ITS5 and one microliter was used in PCR with the Phomopsis-specific primers Phom I and Phom II to check the purity of DNA extraction (39).

Assay development for TaqMan chemistry. The 7700 SDS is an integrated hardware and software system capable of performing real-time quantification of nucleic acids. The system includes a built-in 96-well thermal cycler, an argon ion laser that excites the samples at $488 \mathrm{~nm}$, a charge coupled device, a spectrograph that reads emissions ranging from 500 to $650 \mathrm{~nm}$, and a complete software package that automatically analyzes data collected during each run.

Based on the sequence information of the internal transcribed spacer (ITS) regions of ribosomal DNA (rDNA) of $P$. longicolla, D. phaseolorum var. caulivora, D. phaseolorum var. meridionalis, and D. phaseolorum var. sojae (40), TaqMan primer/probe sets PL-3, PL-5, and DPC-3 were designed, using Primer Express (Perkin-Elmer Applied Biosystems), that would discriminate different Diaporthe and Phomopsis variants. All three sets were designed according to the original guidelines developed by Livak et al. (22) and recently modified using the $2 X$ Universal Master Mix (P/N 4304449; Perkin-Elmer Applied Biosystems). The specificity and sensitivity of the TaqMan primer/probe sets were tested using genomic DNA from eight isolates of $P$. longicolla, four isolates each from $D$. phaseolorum var. caulivora and $D$. phaseolorum var. meridionalis, two isolates of $D$. phaseolorum var. sojae, nine isolates of other soybean fungal pathogens (Table 1), a leaf sample from a healthy soybean plant, healthy appearing soybean seeds, and $P$. longicolla-infected soybean seeds.

One seed lot sample from Italy (I3) had a Diaporthe and Phomopsis infection frequency of $27 \%$ and a P. longicolla infection frequency of $18 \%$, based on PDA plating. The results from these samples were compared with those obtained by TaqMan analysis using primer/probe set PL-3.

TaqMan PCR conditions and analysis. Soybean seed extract (0.5 ng) (purified DNA template) was mixed with $1 \times$ TaqMan buffer; $5 \mathrm{mM} \mathrm{MgCl}{ }_{2} ; 8 \%$ glycerol; $200 \mu \mathrm{M}$ each of dATP, dCTP, and dGTP; $400 \mu \mathrm{M}$ dUTP; $0.3 \mu \mathrm{M}$ forward primer; $0.3 \mu \mathrm{M}$ reverse primer; 100-nm probe; 0.5 units of AmpliTaqGold (Perkin-Elmer Applied Biosystems); and 0.5 units of AmpErase Uracil-n-glycosylase (Perkin-Elmer Applied Biosystems). Samples were incubated for $10 \mathrm{~min}$ at $50^{\circ} \mathrm{C}$ and $5 \mathrm{~min}$ at $95^{\circ} \mathrm{C}$ and then subjected to 40 cycles 
of $95^{\circ} \mathrm{C}$ for $15 \mathrm{~s}$ and $60^{\circ} \mathrm{C}$ for $1 \mathrm{~min}$. Total PCR volume was $50 \mu \mathrm{l}$, and all samples were run in triplicate.

The 7700 SDS automatically collects data in "real time," as one data point is collected every $7 \mathrm{~s}$ from each of the 96 sample wells, generating a fluorescence profile of the amplification. Multicomponenting compares the raw data with a pure dye profile to determine the contribution of the different dyes in each reaction. The dyes utilized included the reporter dye (6-FAM; Oligo Factory, PerkinElmer Applied Biosystems), a quencher dye (TAMRA; Oligo Factory), and an internal reference dye (ROX; Oligo Factory) found in the TaqMan buffer. Following multicomponenting, the reporter dye was normalized to ROX and the baseline value was subtracted. Once accumulation of normalized fluorescence intersects the threshold value, a level set through the geometric phase of PCR amplification, a cycle number is then interpolated for each sample.

TaqMan assay specificity. Each of the three TaqMan primer/probe sets was tested using known $D$. phaseolorum and $P$. longicolla variants as templates to determine which strains or varieties produced a specific fluorescent signal. Negative samples also were retested in the presence of an internal positive control (IPC). The Exogenous Internal Positive Control Kit (Perkin-Elmer Applied Biosystems) contains a unique, engineered sequence that was spiked into each PCR reaction along with a corresponding TaqMan primer/probe set specific for its nucleic acid sequence. The IPC provides a means to evaluate the performance of the PCR chemistry and to distinguish "false" from "true" negatives. Both the IPC and the target of interest are amplified simultaneously in the same tube. When the target sample was negative and the IPC was positive, a true negative value was recorded. When both the target and the IPC were negative, a "no amp" reading occurred, indicating the PCR reaction failed. This setup helps to eliminate false negatives when determining primer/probe specificity.

TaqMan assay sensitivity and performance. To evaluate the sensitivity and linearity of each assay independently, plasmids of PCR2-1 (TA Cloning Kit, version E; Invitron Corp., San Diego, CA) containing individual fragments of rDNA amplified by primers ITS4 and ITS5 from D. phaseolorum and P. longicolla isolates were produced (described above), quantitated by $\mathrm{OD}_{260}$, and utilized as standards. Ten-fold dilutions ranging from an average of $0.15 \mathrm{fg}$ to $0.15 \mathrm{ng}$ (roughly 4 to $4 \times 10^{6}$ copies) of Diaporthe and Phomopsis clones, clone PL, clone DPC, clone DPM, and clone DPS, were prepared and amplified with sets PL-3, PL-5, and DPC-3. Samples were run in triplicate and labeled as standards. A correlation coefficient and dynamic were then determined for each of the three TaqMan primer/probe sets.

TaqMan assay performance also was evaluated in the face of different nucleic acid preparations. Samples prepared by all three of the previously described DNA isolation methods were examined by TaqMan analysis to determine if DNA fragment length or chemical treatment affects TaqMan assay sensitivity or detection. Furthermore, results of previously characterized samples were compared with those obtained by TaqMan analysis to determine ease of use and accuracy of sample discrimination.

Detection of $D$. phaseolorum and $P$. longicolla in soybean seed lots by PDA plating. Ten surface-sterilized soybean seeds from each of the 13 seed lots used in PCR-RFLP were plated on a PDA plate ( $9 \mathrm{~cm}$ in diameter) (100 seeds for each seed lot were tested) and incubated under fluorescent light of $60 \mu \mathrm{E} \mathrm{m} \mathrm{m}^{-2} \mathrm{~s}^{-1}(12 \mathrm{~h}$ per day) at $25^{\circ} \mathrm{C}$ for 10 to 20 days. Colony characteristics, stroma shapes, and fruiting bodies were observed to determine the frequency of infection by each species and variety.

PCR-RFLP detection of $D$. phaseolorum and $P$. longicolla growing from infected seeds on PDA plugs. One hundred soybean seeds from each of the 13 soybean seed lots, eight from Italy and five from the United States, were plated on PDA medium to detect $D$. phaseolorum and $P$. longicolla. DNA was extracted from mycelia growing out from soybean seeds and amplified using primers ITS4 and ITS5. PCRs were performed with a DNA thermal cycler (Perkin-Elmer Applied Biosystems). Reaction mixture was



TABLE 1. Soybean fungal pathogens used for specificity and to test TaqMan primer/probe sets

\begin{tabular}{|c|c|c|c|}
\hline Code & Fungus & Origin & Contributor $^{\mathrm{a}}$ \\
\hline O1 & Phoma sp. & Illinois, United States & G. L. Hartman \\
\hline $\mathrm{O} 2$ & Alternaria sp. & Illinois, United States & G. L. Hartman \\
\hline $\mathrm{O} 3$ & Alternaria sp. & Illinois, United States & G. L. Hartman \\
\hline $\mathrm{O} 4$ & Penicillium sp. & Illinois, United States & G. L. Hartman \\
\hline O5 & Fusarium solani & Illinois, United States & G. L. Hartman \\
\hline O6 & Drechslera sp. & Illinois, United States & G. L. Hartman \\
\hline O7 & Colletotrichum coccodes & Illinois, United States & G. L. Hartman \\
\hline O8 & Rhizoctonia solani & Illinois, United States & G. L. Hartman \\
\hline O9 & Mucor sp. & Illinois, United States & G. L. Hartman \\
\hline $\mathrm{C} 1$ & Diaporthe phaseolorum var. caulivora & Italy & A. Porta-Puglia \\
\hline $\mathrm{C} 2$ & D. phaseolorum var. caulivora & Italy & A. Porta-Puglia \\
\hline C3 & D. phaseolorum var. caulivora & Italy & A. Porta-Puglia \\
\hline $\mathrm{C} 4$ & D. phaseolorum var. caulivora & Italy & A. Porta-Puglia \\
\hline $\mathrm{C} 5$ & D. phaseolorum var. caulivora & Italy & A. Porta-Puglia \\
\hline C6 & D. phaseolorum var. caulivora & Italy & A. Porta-Puglia \\
\hline M1 & D. phaseolorum var. meridionalis & Arkansas, United States & J. Rupe \\
\hline M2 & D. phaseolorum var. meridionalis & Arkansas, United States & J. Rupe \\
\hline M3 & D. phaseolorum var. meridionalis & Arkansas, United States & J. Rupe \\
\hline M4 & D. phaseolorum var. meridionalis & Arkansas, United States & J. Rupe \\
\hline M5 & D. phaseolorum var. meridionalis & Florida, United States & S. A. Rehner \\
\hline M6 & D. phaseolorum var. meridionalis & Arkansas, United States & J. Rupe \\
\hline S1 & D. phaseolorum var. sojae & Arkansas, United States & J. Rupe \\
\hline $\mathrm{S} 2$ & D. phaseolorum var. sojae & South Korea & E. W. Park \\
\hline P1 & Phomopsis longicolla & Italy & A. Porta-Puglia \\
\hline $\mathrm{P} 2$ & P. longicolla & Ohio, United States & G. L. Hartman \\
\hline P3 & P. longicolla & Arkansas, United States & J. Rupe \\
\hline P4 & P. longicolla & Illinois, United States & G. L. Hartman \\
\hline P5 & P. longicolla & Iowa, United States & G. L. Hartman \\
\hline P6 & P. longicolla & Missouri, United States & G. L. Hartman \\
\hline P7 & P. longicolla & Italy & A. Porta-Puglia \\
\hline P8 & P. longicolla & China & G. L. Hartman \\
\hline
\end{tabular}


etteville; S. A. Rehner, USDA/ARS, Beltsville, MD; and E. W. Park, Seoul National University, Suwon, South Korea. 
$0.2 \mathrm{mM}$ each of dTTP, dATP, dGTP, and dCTP; $50 \mathrm{pmol}$ of the primers; 2.5 units $T a q$ polymerase (Gibco BRL Corp., Grand Island, $\mathrm{NY}$ ); and $25 \mathrm{ng}$ of genomic DNA in a final volume of $50 \mu \mathrm{l}$. Reactions were incubated at $96^{\circ} \mathrm{C}$ for $3 \mathrm{~min}$, followed by 30 cycles of $94^{\circ} \mathrm{C}$ for $1 \mathrm{~min}, 55^{\circ} \mathrm{C}$ for $1 \mathrm{~min}$, and $72^{\circ} \mathrm{C}$ for $2 \mathrm{~min}$. The amplification efficiency was checked by agarose gel electrophoresis using $5 \mu \mathrm{l}$ of the PCR product (38).

PCR products from the ITS region were digested with the restriction enzymes AluI, MseI, HhaI, RsaI, and ScrFI according to the manufacturer's recommendations (Gibco BRL Corp. and New England Biolabs Corp., Beverly, MA) using $7 \mu$ of the PCR product (approximately 200 to $500 \mathrm{ng}$ of DNA), $1.5 \mu \mathrm{l}$ of buffer (10X), and $6.5 \mu \mathrm{l}$ of $\mathrm{ddH}_{2} \mathrm{O}$ containing 5 to 10 units of restriction enzyme at $37^{\circ} \mathrm{C}$ for 2 to $4 \mathrm{~h}$. Enzyme-digested PCR products were sizefractionated on a mixed agarose gel of $1 \%$ ultra pure agarose (Gibco BRL Corp.) and 1\% 3:1 high-resolution blended agarose (Amresco, Solon, $\mathrm{OH}$ ) at $3.5 \mathrm{~V} / \mathrm{cm}$, stained with ethidium bromide, visualized on a UV transilluminator, and photographed. A 1-kb double-stranded DNA ladder (Gibco BRL Corp.) was used as a size marker. According to the banding patterns specific to $P$. longicolla, $D$. phaseolorum var. caulivora, $D$. phaseolorum var. meridionalis, and D. phaseolorum var. sojae (40), the infection frequencies of $D$. phaseolorum and $P$. longicolla were obtained.

The sensitivity of PCR-RFLP detection was tested by taking $10 \mathrm{ng}$ of pure D. phaseolorum and $P$. longicolla DNA per $\mu$ l diluted from $10^{-1}$ to $10^{-10}$. Dilutions were run through a PCR using primers ITS4 and ITS5. The PCR protocol and product visualization by agarose gel analysis followed a previous publication (40).

Cost comparison of the different detection methods. Costs were compared based on the reagents, probes, plastics, agarose, buffers, and other supplies using competitive prices from various companies. Time was not considered as a cost, but it was estimated for each procedure.

\section{RESULTS}

Fungal DNA extraction from soybean seeds. The quality and quantity of extracted DNA and the estimated time to conduct each



Fig. 1. DNA fragment lengths using liquid nitrogen, mini-beadbeater, and ultrasonic processor to break the soybean cells for DNA extraction. Lanes 1 and 8, 1-kb DNA ladders. Lane 2, DNA extracted by liquid nitrogen. Lane 3, DNA extracted by mini-beadbeater treatment. Lanes 4 to 7 , DNA extracted by the ultrasonic processor. of three techniques are listed in Table 2. The average DNA fragment length retained when liquid nitrogen and minibeads were utilized was over 4,000 base pairs (bp) (Fig. 1, lanes 2 and 3), while the DNA fragment length range retained after the ultrasonic processor treatment was 200 to $1,200 \mathrm{bp}$, with the majority of fragments averaging less than $500 \mathrm{bp}$ (Fig. 1, lanes 4 to 7). The highest DNA yield was $35 \mu \mathrm{g}$ per seed coat, obtained with the ultrasonic processor, compared with DNA yields of 18 to $20 \mu \mathrm{g}$ per seed coat from liquid nitrogen and minibeads. The ultrasonic processor was the fastest preparation method, requiring only $1 \mathrm{~h}$ for 50 single soybean seeds; this was three to six times faster than using minibeads and liquid nitrogen, respectively (Table 2).

DNA fragments isolated by the ultrasonic processor were amplified with the universal primers ITS4 and ITS5. This reaction pro-



Fig. 2. Amplification of DNA extracted using an ultrasonic processor with the universal primers ITS4 and ITS5. Lanes 1 and 10, 1-kb DNA ladders. Lane 2, Amplified Phomopsis DNA from pure liquid culture. Lane 3, Amplified soybean DNA from a healthy seedling. Lane 4, Amplified Phomopsis DNA from mycelial grow-outs on potato dextrose agar originating from an infected soybean seed. Lanes 5 to 8, Amplified DNA from individual infected soybean seeds. Lane 9, Amplified soybean DNA from a healthy seed.



Fig. 3. Amplification of DNA extracted using an ultrasonic processor with the Phomopsis-specific primers Phom I and Phom II. Lanes 1 and 10, 1-kb DNA ladders. Lane 2, Amplified Phomopsis DNA from pure liquid culture. Lane 3, Amplified soybean DNA from a healthy seedling. Lane 4, Amplified Phomopsis DNA from mycelial grow-outs on potato dextrose agar originating from an infected soybean seed. Lanes 5 to 8, Amplified DNA from individual infected soybean seeds. Lane 9, Amplified soybean DNA from a healthy seed.

TABLE 2. Comparison of DNA extraction methods used on 50 individual soybean seed coat cells

\begin{tabular}{|c|c|c|c|c|c|c|}
\hline Technique & $\begin{array}{c}\text { Seed } \\
\text { condition }^{\mathrm{a}}\end{array}$ & $\begin{array}{c}\text { DNA yield } \\
(\mu \mathrm{g} / \text { seed coat })^{\mathrm{b}}\end{array}$ & $\begin{array}{l}\text { DNA fragment length } \\
\text { (bp) }\end{array}$ & $\begin{array}{c}\text { ITS4, ITS5 } \\
\text { amplification }^{\mathrm{c}}\end{array}$ & $\begin{array}{l}\text { Phom I, Phom II } \\
\text { amplification }^{\mathrm{d}}\end{array}$ & $\begin{array}{l}\text { Time } \\
\text { (h) }\end{array}$ \\
\hline \multirow[t]{2}{*}{ Liquid nitrogen } & Healthy & 30 & 4,000 & Single band & - & 6 \\
\hline & Infected & 30 & 4,000 & Double bands & + & \\
\hline \multirow[t]{2}{*}{ Mini-beadbeater } & Healthy & 28 & 4,000 & Single band & - & 3 \\
\hline & Infected & 28 & 4,000 & Double bands & + & \\
\hline \multirow[t]{2}{*}{ Ultrasonic processor } & Healthy & 35 & $200-1,200$ & Single band & - & 1 \\
\hline & Infected & 35 & $200-1,200$ & Double bands & + & \\
\hline
\end{tabular}

a Soybean seeds infected by Diaporthe and Phomopsis.

b DNA yields were measured by UV spectrometer at $260 \mathrm{~nm}$.

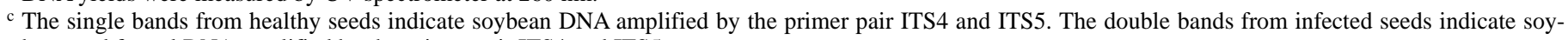
bean and fungal DNA amplified by the primer pair ITS4 and ITS5.

d Primer pair Phom I and Phom II are Diaporthe- and Phomopsis-specific primers. 
duced a single band approximately $600 \mathrm{bp}$ in length for all samples (Fig. 2, lane 2). In comparison, a single band approximately $750 \mathrm{bp}$ in length (Fig. 2, lanes 3 and 9) was obtained from all soybean DNA samples run under the same PCR conditions. DNA extracted from infected soybean seeds and subjected to PCR with the same ITS primers produced 600- and 750-bp bands (Fig. 2, lanes 4 to 7). In contrast, when the Phomopsis-specific primers Phom I and Phom II were utilized to amplify the DNA fragments extracted from ultrasonic processor, only pure Phomopsis DNA and Phomopsis-infected soybean DNA produced a specific band of 337 bp (Fig. 3, lanes 2 and 4 to 8 ).

Detection of $\boldsymbol{D}$. phaseolorum and $\boldsymbol{P}$. longicolla from soybean seeds by the TaqMan assay. The sequences, locations, and amplified DNA fragment lengths of TaqMan primer/probe sets specific to $D$. phaseolorum and $P$. longicolla are listed in Table 3 . None of the TaqMan primer/probe sets significantly amplified DNA extracted from healthy soybean leaves or seeds, indicating no crossreactivity with any other genomic DNA or endogenous nucleic acid present in the sample preparations.

The primer/probe set PL-5 amplified a 96-bp fragment corresponding to 142 to $237 \mathrm{bp}$ of the ITS1 region. Set PL-3 amplified a 86-bp DNA fragment corresponding to 398 to 483 bp within the ITS2 region. Set DPC-3 amplified a 151-bp DNA fragment ranging from 382 to 532 bp also within the ITS2 region.

A ten-fold dilution series of Phomopsis plasmids, PL-3, PL-5, and DPC-3, detected as little as $0.15 \mathrm{fg}$ of pure DNA. Samples were run in triplicate and labeled as standards in order to evaluate

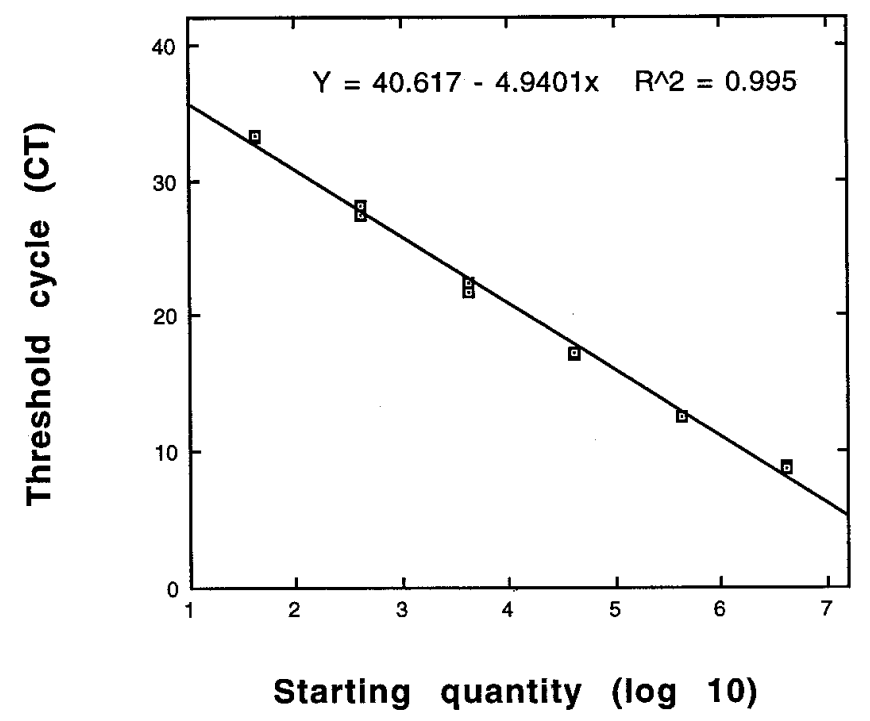

Fig. 4. Standard curve of serial dilutions of plasmid PL-1 amplified by using TaqMan primer/probe set PL-5. the sensitivity and linearity of each assay independently. Each standard produced curves that routinely had an $r>0.987$, with a linear dynamic range of 5 logs (Fig. 4). The results were similar for all three TaqMan primer/probe sets.

All three TaqMan primer/probe sets were normalized to healthy seed (HS $=1.0$ ) and plotted as the log (relative quantity) of pathogen present per $0.5 \mathrm{ng}$ of total DNA. Nine soybean fungal pathogens, excluding Diaporthe and Phomopsis (Figs. 5 to 7), tested negative for each of the three TaqMan primer/probe sets. Set PL-5 detected P. longicolla, D. phaseolorum var. meridionalis, and $D$. phaseolorum var. sojae (Fig. 5). Set PL-3 only reacted with $P$. longicolla, with $5 \times 10^{5}$ molecules more than the other species (Fig. 6). Some minor cross-reactivity was observed with $D$. phaseolorum var. meridionalis and $D$. phaseolorum var. caulivora, but it was less than that of healthy seed. Set DPC-3 was specific for only D. phaseolorum var. caulivora (Fig. 7). All other samples tested with this set showed negative results

PCR-RFLP, PDA plating, and TaqMan assay for Diaporthe and Phomopsis detection from soybean seed lots. By PCRRFLP detection, the total Diaporthe and Phomopsis detected among 13 soybean seed lots ranged from 0 to $32 \%$ (Table 4). P. longicolla was the most prevalent, with an average infection frequency of

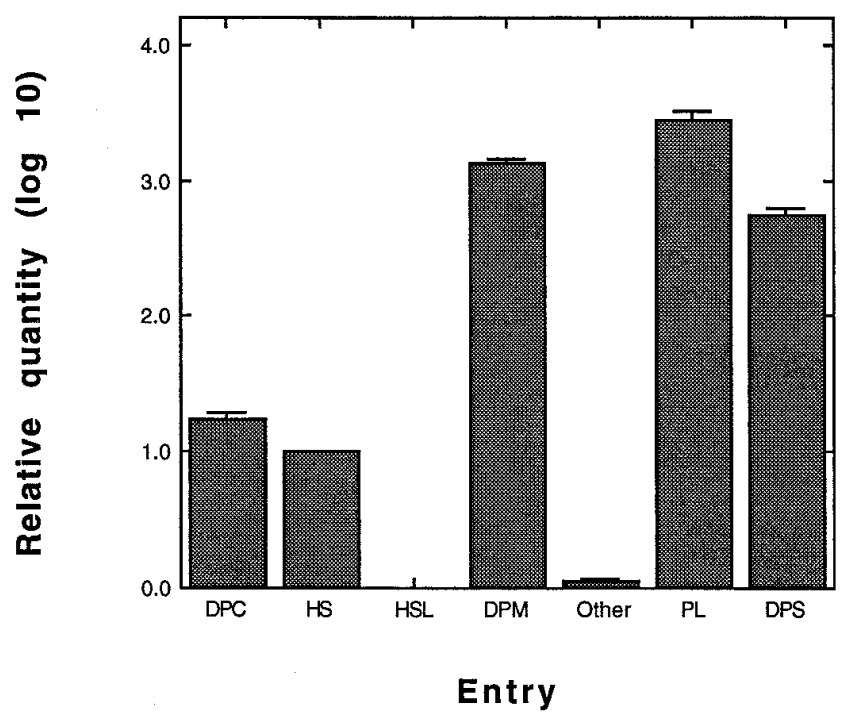

Fig. 5. Specificity of TaqMan primer/probe set PL-5 to 13 soybean fungal pathogens. Data are plotted as log quantity of pathogen detected relative to healthy seed $(\mathrm{HS}=1.0)$. DPC = Diaporthe phaseolorum var. caulivora, $\mathrm{HS}=$ healthy soybean seed, $\mathrm{HSL}=$ healthy soybean leaf, $\mathrm{DPM}=D$. phaseolorum var. meridionalis (mean of six isolates), Other $=$ other soybean fungal pathogens (nine species), $\mathrm{PL}=$ Phomopsis longicolla (mean of seven isolates), and DPS $=D$. phaseolorum var. sojae (mean of two isolates). Vertical bars represent standard error of the means.

TABLE 3. TaqMan primer/probe sets for detection of Diaporthe phaseolorum var. caulivora (DPC), D. phaseolorum var. meridionalis (DPM), and Phomopsis longicolla (PL) from soybean seeds



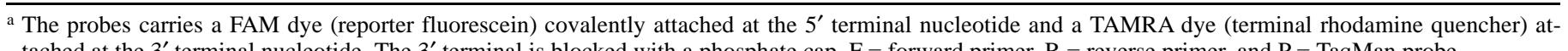
tached at the $3^{\prime}$ terminal nucleotide. The $3^{\prime}$ terminal is blocked with a phosphate cap. $\mathrm{F}=$ forward primer, $\mathrm{R}=$ reverse primer, and $\mathrm{P}=$ TaqMan probe.

b TaqMan amplicon position within the internal transcribed spacer region of ribosomal DNA. 
$7.3 \%$ in Italian seed lots and $11.4 \%$ in U.S. seed lots; followed by D. phaseolorum var. sojae, which had an infection frequency of $4.8 \%$ in Italian seed lots and $0.6 \%$ in U.S. seed lots. D. phaseolorum var. caulivora was detected in only $0.5 \%$ of seeds from Italian seed lots and in none from the United States. D. phaseolorum var. meridionalis was not detected from Italian or U.S. seed lots. Considering the appropriate visible banding pattern created after digestion, the sensitivity of PCR-RFLP detection was as great as $100 \mathrm{pg}$ of pure Diaporthe and Phomopsis DNA.

The infection frequencies of each seed lot obtained by both PCRRFLP and PDA plating were comparable with respect to total infection and individual species detection (Table 4). Diaporthe and Phomopsis detection in seed lot $\mathrm{I} 3$ using TaqMan primer/probe set PL-3 showed that the P. longicolla infection frequency was $18 \%$ (Fig. 8), which is the same as that obtained from PCR-RFLP and PDA plating.

Cost comparison of the different detection methods. Costs of the detection methods are presented in Table 5. The TaqMan costs



\section{Entries}

Fig. 6. Specificity of TaqMan primer/probe set PL-3 to 13 soybean fungal pathogens. Data is plotted as log quantity of pathogen detected relative to healthy seed $(\mathrm{HS}=1.0)$. DPC = Diaporthe phaseolorum var. caulivora (mean of two isolates), HS = healthy soybean seed, HSL = healthy soybean leaf, $\mathrm{DPM}=D$. phaseolorum var. meridionalis (mean of two isolates), Other $=$ other soybean fungal pathogens (nine species), $\mathrm{PL}=$ Phomopsis longicolla (mean of six isolates), and DPS $=D$. phaseolorum var. sojae (mean of two isolates). Vertical bars represent standard error of the means. reflect list prices with no discounts and, therefore, are indicative of the highest estimate for PCR. Reactions in this table also reflect a $50-\mu$ l volume, although the user may choose a volume between 20 and $100 \mu \mathrm{l}$. Obviously, use of the 25 - $\mu$ l volume further reduces operating and running costs by a factor of 2 . No adverse effects on assay performance, reproducibility, or sensitivity were determined in this study when reaction volumes were reduced to $25 \mu \mathrm{l}$ (data not shown). The total time for TaqMan analysis is less than $2 \mathrm{~h}$ compared with other lengthy incubation periods or post-PCR procedures. Although analysis was not done on labor costs, TaqMan analysis compared with the other techniques provides a significant reduction in time needed to obtain results.

\section{DISCUSSION}

The detection of soybean seedborne pathogens is an important determinant in testing the health of the seeds. Many seed-testing



Fig. 7. Specificity of TaqMan primer/probe set DPC-3 to 13 soybean fungal pathogens. Data is plotted as $\log$ quantity of pathogen detected relative to healthy seed $(\mathrm{HS}=1.0)$. DPC $=$ Diaporthe phaseolorum var. caulivora (mean of six isolates), $\mathrm{HS}=$ healthy soybean seed, $\mathrm{HSL}=$ healthy soybean leaf, DPM $=D$. phaseolorum var. meridionalis (mean of six isolates), Other $=$ other soybean fungal pathogens (nine species), $\mathrm{PL}=$ Phomopsis longicolla (mean of two isolates), and DPS $=D$. phaseolorum var. sojae (mean of two isolates).




agar (PDA) plating for morphological identification

\begin{tabular}{|c|c|c|c|c|c|c|c|c|c|c|}
\hline \multirow[b]{2}{*}{ Seed $\operatorname{lot}^{\mathrm{a}}$} & \multicolumn{5}{|c|}{ PDA morphology observation (\%) } & \multicolumn{5}{|c|}{ PCR-RFLP identification (\%) } \\
\hline & Total & PL & DPS & DPM & $\mathrm{DPC}$ & Total & PL & DPS & DPM & DPC \\
\hline I1 & 14 & 12 & 1 & 0 & 1 & 15 & 13 & 1 & 0 & 1 \\
\hline $\mathrm{I} 2$ & 7 & 3 & 3 & 0 & 1 & 7 & 3 & 3 & 0 & 1 \\
\hline I3 & 27 & 18 & 8 & 0 & 1 & 27 & 18 & 8 & 0 & 1 \\
\hline I4 & 4 & 2 & 2 & 0 & 0 & 4 & 2 & 2 & 0 & 0 \\
\hline I5 & 0 & 0 & 0 & 0 & 0 & 0 & 0 & 0 & 0 & 0 \\
\hline I6 & 6 & 3 & 3 & 0 & 0 & 6 & 3 & 3 & 0 & 0 \\
\hline I7 & 9 & 2 & 7 & 0 & 0 & 9 & 2 & 7 & 0 & 0 \\
\hline I8 & 31 & 16 & 14 & 0 & 1 & 32 & 17 & 14 & 0 & 1 \\
\hline Average & 12.3 & 7.0 & 4.8 & 0 & 0.5 & 12.5 & 7.3 & 4.8 & 0 & 0.5 \\
\hline A5 & 10 & 9 & 1 & 0 & 0 & 11 & 10 & 1 & 0 & 0 \\
\hline A6 & 25 & 24 & 1 & 0 & 0 & 24 & 23 & 1 & 0 & 0 \\
\hline A7 & 6 & 5 & 1 & 0 & 0 & 6 & 5 & 1 & 0 & 0 \\
\hline A8 & 19 & 19 & 0 & 0 & 0 & 19 & 19 & 0 & 0 & 0 \\
\hline A9 & 0 & 0 & 0 & 0 & 0 & 0 & 0 & 0 & 0 & 0 \\
\hline Average & 12 & 11.4 & 0.6 & 0 & 0 & 12 & 11.4 & 0.6 & 0 & 0 \\
\hline
\end{tabular}

a 11 to I8 are the seed lots collected from Italy (Rome), and A5 to A9 are the seed lots collected from the United States (Missouri, Ohio, and Indiana). 
laboratories evaluate soybean seeds for Phomopsis seed decay using traditional detection methods. To detect seedborne pathogens using molecular assays, DNA extraction from seeds is a critical step. Of the three methods tested for breaking soybean seed coats cells, the ultrasonic process had significant advantages over the other two methods. The ultrasonic processor took one-sixth and one-third the time of liquid nitrogen and minibeads, respectively. In addition, the ultrasonic process and the entire DNA extraction process was done in one tube per seed, which eliminated potential contamination points. In addition, the yield of DNA from the ultrasonic process was higher than from the other two methods. The ultrasonic processor broke the DNA into smaller fragments (several hundred bp), which may have allowed for the DNA to be less tangled with cell debris. In this study, only $250 \mu \mathrm{l}$ of extraction buffer was used in a 1.5-ml microfuge tube for each seed coat DNA extraction, so there was little space for released DNA to be freely suspended in such a condensed solution. As a result, the shorter DNA fragments were relatively easier to be resuspended in the supernatant.

Most, but not all, DNA fragments extracted by the ultrasonic process were less than 500 bp (Fig. 1). Even though primers ITS4 and ITS5 amplify DNA fragments approximately $600 \mathrm{bp}$ in length, there were still enough DNA templates for PCR amplification and detection. Genes coding for rDNA in fungi are located on a single chromosome (27) and are present as repeated units configured in



Fig. 8. Detection of Diaporthe and Phomopsis using TaqMan primer/probe set PL-3 from soybean seed lot I3. Data is plotted as log quantity of pathogen detected relative to healthy seed $(\mathrm{HS}=1.0)$. Individual seed $=$ Phomopsis longicolla-infected soybean seed, and HS = healthy appearing soybean seed. head-to-tail arrays with 60 to 220 copies per haploid genome (24). These multiple-gene copies provide sufficient rDNA template for PCR detection with primers ITS4 and ITS5, even though most rDNA was broken into $<500$-bp fragments.

The specific primers Phom I and Phom II amplify DNA fragments 337 bp in length (39). The TaqMan primer/probe sets developed amplified DNA fragments from 86 to $151 \mathrm{bp}$. The ultrasonic process for DNA extraction cuts DNA into mostly $<500$-bp fragments, making it more useful and efficient for the PCR-based pathogen detection of the rDNA region.

Due to the conserved nature of rDNA, it is almost impossible to find polymorphic regions that fit the requirements for both the basic primer properties and the separate identification of $D$. phaseolorum and P. longicolla of soybean isolates (data not shown). In contrast, TaqMan detection has the advantage of an additional level of specificity based on the probe sequence. For the probe to be cleaved and a signal to be released, interaction between the Taq polymerase, primer, template, and probe must form a forklike structure that, in turn, initiates the $5^{\prime}$ nuclease activity of the enzyme (15). This interaction can only take place if all three oligonucleotides are identical to the target sequence of interest and they anneal properly during PCR. Therefore, TaqMan primer/probe sets allow discrimination between homologous targets even in those cases when polymorphic regions between sequences are limited. All three TaqMan primer/probe sets were tested individually against known strains and varieties of fungal pathogens. The results indicate that the three TaqMan probe/primer sets showed excellent discrimination for the sequences from which they were designed and can be used to type the particular pathogen present in soybean seeds (Figs. 5 to 7 ).

During the validation process of the TaqMan assays, initial sensitivity and specificity studies used purified plasmids (described above). These studies were repeated with several positive samples from each of the three DNA preparatory methods described. In all cases, the TaqMan assay retained a similar sensitivity and specificity for the appropriate species (data not shown) compared with that of the data derived from plasmid samples, indicating that quicker, more simplified DNA preparation may be used in conjunction with TaqMan.

The Phomopsis-specific primers Phom I and Phom II distinguish Diaporthe spp. and Phomopsis spp. from other soybean fungal pathogens (39). The TaqMan primer/probe set PL-5 identified $P$. longicolla, D. phaseolorum var. meridionalis, and D. phaseolorum var. sojae, while set PL-3 identified only P. longicolla and set DPC-3 identified only $D$. phaseolorum var. caulivora. With the combination of Phomopsis-specific primers and TaqMan primer/probe sets, $P$. longicolla and $D$. phaseolorum var. caulivora were also distinguished. The remaining isolates should be either $D$. phaseolorum var. meridionalis or D. phaseolorum var. sojae. Because there are differences in pathogenicity, physiology, and epidemiology among

TABLE 5. Relative cost and time of several methods used to detect seedborne pathogens Diaporthe phaseolorum and Phomopsis longicolla per reaction or plate in soybean seeds

\begin{tabular}{|c|c|c|c|c|c|c|c|c|}
\hline Method $^{\mathrm{a}}$ & Reagents (\$) & Probes/primers (\$) & Plastics (\$) & Agarose (\$) & Buffers $(\$)$ & Other $(\$)$ & Time $(\mathrm{h})^{\mathrm{b}}$ & Total \$ \\
\hline TaqMan single & 1.98 & 0.16 & 0.15 & None & None & None & $<2$ & 2.29 \\
\hline TaqMan two ${ }^{c}$ & 1.98 & 0.32 & 0.15 & None & None & None & $<2$ & 2.45 \\
\hline PCR-RFLP & 5.92 & 0.09 & 0.15 & 0.24 & 0.30 & None & 5 & 6.70 \\
\hline Plating assay & 0.8 & None & 0.1 & None & None & None & $>280$ & 0.90 \\
\hline
\end{tabular}

a All polymerase chain reaction (PCR) TaqMan and PCR reactions are calculated based on a 50- $\mu$ l volume. Prices are not based on discounts and actual costs may be lower in laboratories that already are conducting this type of research. Costs do not include lease or purchase of equipment. Assays are easily adaptable to volumes as low as $20 \mu \mathrm{l}$ for further cost reductions.

${ }^{\mathrm{b}}$ Not included in cost analysis.

${ }^{c}$ Price comparisons are shown for both single-probe (one target) and dual-probe (two target) reactions. To avoid false-negative calls in reactions in which no amplification of the pathogen of interest is shown or to account for pipetting and well-to-well variability, reactions may be optimized for two probe reactions and primer sets. The second set is specific for either an endogenous internal control/normalization target or for an artificial internal positive control target that is spiked into the reaction mix. Use of an internal control reduces the reaction number and overall assay cost per sample by a factor of 2 .

${ }^{d}$ Specific primers designed for total infection of $D$. phaseolorum and $P$. longicolla based on previously described methods (39). 
the species and varieties, species identification is a critical step for designing control strategies for these pathogens. Although a suitable TaqMan primer/probe set was not found for D. phaseolorum var. meridionalis and $D$. phaseolorum var. sojae, it seems possible to design a TaqMan primer/probe set for this purpose by researching other polymorphic regions of genomic DNA.

The sensitivities of the TaqMan primer/probe sets detected as little as $0.15 \mathrm{fg}$ of DNA templates, while PCR-RFLP required $100 \mathrm{pg}$. The TaqMan 7700 SDS was able to amplify weak signals by monitoring the fluorescence intensity over cycle threshold, while PCRRFLP detection needs sufficient amplified PCR final product for restriction enzyme digestion to create visible banding patterns (40).

Not only was the TaqMan system more sensitive, it also reduced time and labor and was the quickest among all known PCRbased detection techniques $(9,12,21)$. TaqMan detection shortens amplified DNA fragment length and has a unique combination of a built-in thermal cycler, a fluorescence detector, and real-time sequencing detection software that makes detection synchronous. Conventional PCR detection utilizes agarose gel electrophoresis to observe the PCR reaction result. The DNA fragments have to be over $200 \mathrm{bp}$ (usually around 400 to $600 \mathrm{bp}$ ) to be in the reliable visual range, which requires longer DNA extension time. For TaqMan detection, the DNA fragments can be less than $150 \mathrm{bp}$. The entire TaqMan PCR reaction can be done in 35 to 40 cycles, requiring $1 \mathrm{~h}$ 50 min compared with $4 \mathrm{~h}$ required for regular PCR detection. The automatic and simultaneous signal transport from the thermal cycler to computer combined with automatic analysis allows TaqMan detection to save time and labor.

Because TaqMan requires no gel analysis and its associated costs, running buffers, agarose, electrophoresis equipment, ethidium bromide/gel stains, hybridization membranes, radioactivity, oligonucleotide probes, densitometry equipment, x-ray film, and cassettes are all obsolete with this technique. The total time for TaqMan analysis is less than $2 \mathrm{~h}$ and it provides reliable, quantitative information not just subjective, qualitative analysis or visualization such as RFLP or plating techniques. In addition to the time and cost savings, TaqMan assays employ a quick start assay development procedure. This nine-step system follows the protocol of the TaqMan Universal PCR Master Mix (Perkin-Elmer, Foster City, CA). The procedure includes the use of primer/probe design software and guidelines (Primer Express) for fast and easy oligonucleotide design, universal reagent conditions, and a universal thermal cycling protocol.

It has been documented that $P$. longicolla, followed by $D$. phaseolorum var. sojae, are the major fungi of the Diaporthe/Phomopsis complex on soybean seeds $(16,26,31)$. In this study, three separate methods were used to detect these pathogens in 13 soybean seed lots collected from Italy and the United States. Among the seed lots tested, the frequency of $D$. phaseolorum var. caulivora was very low $(<0.5 \%)$, while that of $D$. phaseolorum var. meridionalis was zero, confirming other reports about its low seedborne frequency (26).

The TaqMan detection of these fungi in seeds corresponded to detection obtained from PDA plating and PCR-RFLP. Considering the significant time and labor savings compared with other techniques, TaqMan technology gives greater power to pathogen assays, lending to the possibility of adoption by seed-testing laboratories and other researchers interested in accurate, fast, and reliable detection of pathogens in leaf tissues or seeds.

\section{LITERATURE CITED}

1. Alvarez, E., Braun, E. J., and McGee, D. C. 1995. New assays for detection of Pseudomonas syringae pv. glycinea in soybean seed. Plant Dis. 79:12-14.

2. Beck, J. J., and Ligon, J. M. 1995. Polymerase chain reaction assays for the detection of Stagonospora nodorum and Septoria tritici in wheat. Phytopathology 85:319-324.

3. Brill, L. M., McClary, R. D., and Sinclair, J. B. 1994. Analysis of two
ELISA formats and antigen preparations using polyclonal antibodies against Phomopsis longicolla. Phytopathology 84:173-179.

4. Brunel, D. 1994. A microsatellite marker in Helianthus annuus L. Plant Mol. Biol. 24:397-400.

5. Chen, W., Gray, L. E., and Grau, C. R. 1996. Molecular differentiation of fungi associated with brown stem rot and detection of Phialophora gregata in resistant and susceptible soybean cultivars. Phytopathology 86: $1140-1148$.

6. Edwards, K., Johnstone, C., and Thompson, C. 1991. A simple and rapid method for the preparation of plant genomic DNA for PCR analysis. Nucleic Acids Res. 19:1349.

7. Fernandez, F. A., and Hanlin, R. T. 1996. Morphological and RAPD analysis of Diaporthe phaseolorum from soybean. Mycologia 88:425-440.

8. Garmer, H. R. 1994. Automating the PCR process. Pages 183-192 in: The Polymerase Chain Reaction. K. B. Mullis, F. Ferre, and R. A. Gibbs, eds. K. B. Birkhauser, Boston.

9. Gibson, U. 1996. A novel method for real time quantitative RT-PCR. Genome Res. 6:995-1001.

10. Gleason, M. L., and Ferriss, R. S. 1985. Influence of soil water potential on performance of soybean seeds infected by Phomopsis sp. Phytopathology 75:1236-1241.

11. Gleason, M. L., Ghabrial, S. A., and Ferriss, R. S. 1987. Serological detection of Phomopsis longicolla in soybean seeds. Phytopathology 77 : 371-375.

12. Held, C. 1996. Real time quantitative PCR. Genome Res. 6:986-994.

13. Hepperly, P. R., and Sinclair, J. B. 1978. Quality losses in Phomopsisinfected soybean seeds. Phytopathology 68:1684-1687.

14. Hobbs, T. W., Schmitthenner, A. F., and Kutter, G. A. 1985. A new Phomopsis species from soybean. Mycologia 77:535-544.

15. Holland, P. M., Abramson, R. D., Watson, R., and Gelfand, D. 1991. Detection of specific polymerase chain reaction products by utilizing the 5'-3' exonuclease activity of Thermus aquaticus DNA polymerase. Proc. Natl. Acad. Sci. U.S.A. 88:7276-7280.

16. Kmetz, K. T., Schmitthenner, A. F., and Ellett, C. W. 1978. Soybean seed decay: Prevalence of infection and symptom expression caused by Phomopsis sp., Diaporthe phaseolorum var. sojae, and D. phaseolorum var. caulivora. Phytopathology 68:836-840.

17. Kurkela, S., and Franck, M. 1990. Cloning and characterization of a cold- and ABA-inducible Arabidopsis gene. Plant Mol. Biol. 15:137-144.

18. Langridge, U., Schwall, M., and Langridge, P. 1991. Squashes of plant tissue as substrate for PCR. Nucleic Acids Res. 19:6954.

19. Lee, L. G., Connell, C. R., and Bloch, W. 1993. Allelic discrimination by nick-translation PCR with fluorogenic probes. Nucleic Acids Res. 21: 3761-3766.

20. Levy, L., Lee, I. M., and Hadidi, A. 1994. Simple and rapid preparation of infected plant tissue extracts for PCR amplification of virus, viroid, and MLO nucleic acids. J. Virol. Methods 49:295-304.

21. Livak, K. J. 1998. Quantification of DNA/RNA Using Real-Time PCR Detection. PE-ABD Response Piece. Perkin-Elmer Applied Biosystems Division, Foster City, CA.

22. Livak, K. J., Flood, S. J. A., Marmaro, J., Giusti, W., and Deetz, K. 1995. Oligonucleotides with fluorescent dyes at opposite ends provide a quenched probe system useful for detecting PCR products and nucleic acid hybridization. PCR Methods Appl. 4:357-362.

23. Lyamichev, V., Brow, M. A. D., and Dahlberg, J. E. 1993. Structure specific endonucleolytic cleavage of nucleic acids by eubacterial DNA polymerases. Science 260:778-783.

24. Martin, F. N. 1990. Variation in the ribosomal DNA repeat unit within single-oospore isolates of the genus Pythium. Genome 33:585-591.

25. McGarvey, P., and Kaper, J. M. 1991. A simple and rapid method for screening transgenic plants using the PCR. Biotechniques 11:428-432.

26. Morgan-Jones, G. 1985. The Diaporthe/Phomopsis complex: Taxonomic considerations. Pages 1699-1706 in: Proceedings of the World Soybean Research Conference IV. A. Pascale, ed. Orientación Gráfica, Buenos Aires, Argentina.

27. Petes, T. D., and Botstein, D. 1977. Simple Mendelian inheritance of ribosomal DNA of yeast. Proc. Natl. Acad. Sci. U.S.A. 74:5091-5095.

28. Schaad, N. W., Cheong, S. S., Tamaki, S., Hatziloukas, E., and Panopoulos, N. J. 1995. A combined biological and enzymatic amplification (BIOPCR) technique to detect Pseudomonas syringae pv. phaseolicola in bean seed extracts. Phytopathology 85:243-248.

29. Schilling, A. G., Möller, E. M., and Geiger, H. H. 1996. Polymerase chain reaction-based assays for the detection for species-specific detection of Fusarium culmorum, F. graminearum, and F. avenaceum. Phytopathology 86:515-522.

30. Schoen, C. D., Knorr, D., and Leone, G. 1996. Detection of potato leafroll virus in dormant potato tubers by immunocapture and a fluorogenic 5' nuclease RT-PCR assay. Phytopathology 86:993-999.

31. Sinclair, J. B. 1982. Seed testing: Detection of pathogens. Pages 112-115 
in: Soybean Seed Quality and Stand Establishment. INTSOY Series No. 22. J. B. Sinclair and J. A. Jacobs, eds. University of Illinois, UrbanaChampaign.

32. Sinclair, J. B. 1993. Phomopsis seed decay of soybeans-A prototype for studying seed disease. Plant Dis. 77:329-334.

33. Sinclair, J. B., and Backman, P. A. 1989. Compendium of Soybean Diseases. 3rd ed. The American Phytopathological Society, St. Paul, MN.

34. Singh, T., and Sinclair, J. B. 1986. Further studies on the colonization of soybean seeds by Cercospora kikuchii and Phomopsis sp. Seed Sci. Technol. 14:71-77.

35. Tullis, R. H. 1994. Ultrasensitive nonradioactive detection of PCR reactions: An overview. Pages 123-133 in: The Polymerase Chain Reaction. K. B. Mullis, F. Ferre, and R. A. Gibbs, eds. K. B. Birkhauser, Boston.

36. Velicheti, R. K., Lamison, C., Brill, L. M., and Sinclair, J. B. 1993. Immunodetection of Phomopsis species in asymptomatic soybean plants. Plant Dis. 77:70-73.
37. Wallen, V. R., and Seaman, W. L. 1963. Seed infection of soybean by Diaporthe phaseolorum and its influence on host development. Can. J. Bot. 41:113-121.

38. White, T. J., Bruns, T., Lee, S., and Taylor, J. 1990. Amplification and direct sequencing of fungal ribosomal RNA genes for phylogenetics. Pages 315-322 in: PCR Protocols. A Guide to Methods and Applications. M. A. Innis, D. H. Gelfand, J. J. Sninsky, and T. J. White, eds. Academic Press, Inc., New York.

39. Zhang, A. W., Hartman, G. L., Riccioni, L., Chen, W. D., Ma, R. Z., and Pedersen, W. L. 1997. Using PCR to distinguish Diaporthe phaseolorum and Phomopsis longicolla from other soybean fungal pathogens and to detect them in soybean tissues. Plant Dis. 81:1143-1149.

40. Zhang, A. W., Riccioni, L., Pedersen, W. L., Kollipara, K. P., and Hartman, G. L. 1998. Molecular identification and phylogenetic grouping of Diaporthe phaseolorum and Phomopsis longicolla isolates from soybean. Phytopathology 88:1306-1314. 